\title{
Protein Extraction from Grape Seeds by Reverse Micelles: Optimization of the Forward Extraction
}

\author{
Xifeng Zhang1,2, Yunyun Hou1 ${ }^{1}$, Fenqin Zhang1,2*, Guanghong Luo ${ }^{1,2 *}$ \\ ${ }^{1}$ The College of Agriculture and Biotechnology (CAB), Hexi University, Zhangye, China \\ ${ }^{2}$ Key Laboratory of Hexi Corridor Resources Utilization of Gansu, Zhangye, China \\ Email: *curiouslysxsd@163.com
}

How to cite this paper: Zhang, X.F., Hou, Y.Y., Zhang, F.Q. and Luo, G.H. (2017) Protein Extraction from Grape Seeds by Reverse Micelles: Optimization of the Forward Extraction. Open Access Library Journal, 4: e3376.

https://doi.org/10.4236/oalib.1103376

Received: January 13, 2017

Accepted: June 5, 2017

Published: June 8, 2017

Copyright $\odot 2017$ by authors and Open Access Library Inc.

This work is licensed under the Creative Commons Attribution International License (CC BY 4.0).

http://creativecommons.org/licenses/by/4.0/

\begin{abstract}
The optimization of the reverse micelles extraction of protein from grape seeds was carried out using response surface methodology (RSM). Based on the Plackett-Burman design and steepest ascent, CTAB concentration, $\mathrm{pH}$, $\mathrm{NaCl}$ concentration and crude protein concentration were selected as the most extract conditions. Subsequently, the optimum combination of the selected factors was investigated by the Box-Behnken design. The final condition of extraction optimized with RSM was CTAB concentration $39 \mathrm{mmol} / \mathrm{L}$, $\mathrm{pH} 5.6, \mathrm{NaCl}$ concentration $0.01 \mathrm{~mol} / \mathrm{L}$, and crude protein concentration 2.1 $\mathrm{mg} / \mathrm{mL}$. The forward extraction yield of $82.3 \%$ in triplicate under optimal extraction condition was obtained.
\end{abstract}

\section{Subject Areas}

Food Science \& Technology

\section{Keywords}

Reverse Micelles, Response Surface Methodology, Grape Seeds, Protein

\section{Introduction}

The grape is one of the major fruit crops worldwide and its harvest is about 60 million tonnes per year [1]. About $80 \%$ of the harvest is utilized for winemaking and the grape waste consists the $20 \%$ of the weight of processed grapes. However, winemaking leads to the generation of large quantities of wastes, which considerably increase the chemical oxygen demand (COD) and the biochemical oxygen demand $\left(\mathrm{BOD}_{5}\right)$ due to a high pollution load (high content of organic substances such as sugars, tannins, polyphenols, polyalcohols, pectins and lipids) 
with detrimental effects on the flora and fauna of discharged zones [2].

Therefore, treatment and disposal of winery waste are serious environmental problems and winery waste must find another use other than as animal feed or as fertilizers.

Grape seeds are the primary main byproducts of viniculture and fermentation. In the last few years, increased attention has been focused on industrial wastes that are rich source of polyphenolic compounds, flavonoids, protein and oil [3] [4] [5] [6]. Grape seeds extract in particular show interesting biological properties, such as antioxidant, anticancer, anti-inflammation, anti-aging and anti-bacterical activities [2] [7]-[12].

Grape seeds have relatively high content of protein (13\% - 18\%), which can be extracted by conventional procedures such as solvent extraction and isoelectric precipitation [13] [14] [15]. However, this method has some fatal defects: a great deal of wastewater is produced which causes serious environmental pollution and it is also limited capacity of raw material treatment and high consumption of acid and alkali. Moreover, it is easy to cause protein denaturation. Therefore, it is imperative to explore an alternative extraction approach of grape seeds proteins.

The reverse micelles extraction is a novel separation technology with prospect for separating bio-product. Reverse micelles are aggregates of surfactant molecules spontaneously in non-polar solvents. The aggregates of surfactant molecules contain an inner core of water molecules and are dispersed in a continuous organic solvent medium. The bio-molecules can be transferred from the aqueous phase to the polar core of reverse micelles without loss in activity [16], mainly because of the attractive electrostatic interaction between the inner micelle charge wall and the bio-molecules. Optimization of extraction conditions has been used in enhancing the yield of many proteins [17] [18] [19] [20] [21]. However, there is no literature reported to optimize the extraction conditions for grape seeds protein using reverse micelles. Thus, the main aim of the present work was to optimize the conditions for proteins extraction by reversed micelles from grape seeds. The objective of this study was to develop an alternative extraction method of grape seeds protein by reverse micelles, and to investigate the effects of factors (CTAB concentration, extraction time, crude protein concentration, temperature, $\mathrm{NaCl}$ concentration, $\mathrm{pH}$, alkyl alcohol than) on the forward extraction efficiency of grape seeds protein. Response surface methodology (RSM) was used to optimize the extraction conditions for enhancing the forward extraction efficiency of grape seeds protein by implementing the Box-Behnken experimental design [22].

\section{Materials and Methods}

\subsection{Materials}

Grape seeds were obtained from Palieri grape cultivar. Ceryl-trimethyl-ammonium bromide (CTAB), sodium chloride were purchased from the 6th Chemical 
Reagent Factory of Tianjin, Chin. Other materials used in this study were of analytical grade.

\subsection{Sample Preparation}

Grape seeds were selected manually and cleaned to remove contaminants. Grape seeds were milled using a small scale hammer mill (FZ-102, Hebei province, China), and the resulting flour was sieved through a 200-mesh screen. Grape seeds power was defatted with $\mathrm{n}$-hexane for $10 \mathrm{~h}$ and air-dried at room temperature (about $20^{\circ} \mathrm{C}$ ) by Soxhlet extraction. The power was kept in polyethylene bags and stored at $4^{\circ} \mathrm{C}$ until used.

\subsection{Extraction of Crude Protein}

Defatted grape seeds power was soaked by $0.2 \mathrm{~mol} / \mathrm{L}$ citric acid-sodium hydrogen phosphate buffer solution at $\mathrm{pH} 6.0$ for $1 \mathrm{~h}$. The solution and residue were isolated by a centrifuge at a rolling speed of $4000 \mathrm{rpm}$ and $4^{\circ} \mathrm{C}$ for $10 \mathrm{~min}$. The crude protein was collected.

\subsection{Reversed Micellar Extraction}

The reversed micelles systems were formed by Ceryl-trimethyl-ammonium bromide (CTAB), methenyl trichoride and butyl alcohol. The aqueous solutions were crude protein after centrifugation. Sodium chloride was added to the aqueous solution to adjust the ionic strength. For the forward extraction, equal volumes of the reverse micellar systems (the organic solution) and aqueous solution were mixed in a test tube in a reciprocating shaker bath for various time periods and temperatures. The mixture was then centrifuged at $1500 \mathrm{~g}$ for $5 \mathrm{~min}$ to separate the two phases. The aqueous phase was then taken for analysis. All the experiments were carried out in duplicate.

\subsection{Protein Determination [23]}

Protein concentration in water phase was determined by UV-Vis spectrophotometer (LabTech UV-2100, Beijing). BSA was used as standard, and the results were expressed as BSA equivalents. The forward-extraction efficiency was calculated as follows.

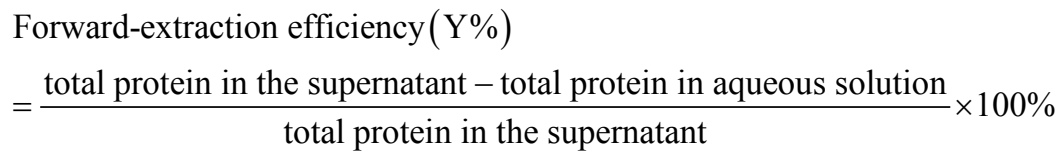

\subsection{Screening of the Forward Extraction Conditions Using a Plackett-Burman Design}

Plackett-Burman design, an efficient technique for forward extraction conditions optimization [24], was used to pick factors that significantly influenced extraction yield and insignificant ones were eliminated in order to obtain a smaller, more manageable set of factors. The extraction conditions were screened by Plackett-Burman design for seven variables at two levels. The main effect of each 
variable was simply calculated as the difference between the average of measurements made at the high setting and the average of measurements observed at the low setting of that factor.

\subsection{Steepest Ascent}

After selecting the most important factor affecting the forward extraction yield in the screening study, the steepest ascent method was used to construct a line through the center of the design [25], due to the contribution obtained by Plackett-Buman design. Consequently, some experiments were implemented along this line with intervals, and the response at each point was measured. If a maximum value is found, that point could be employed as the center point for the following optimization experimental design.

\subsection{Optimization of the Forward Extraction Conditions Using a Box-Behnken Design}

Once critical factors were identified via screening, a Box-Behnken design for the most important independent variables (CTAB concentration, $\mathrm{pH}, \mathrm{NaCl}$ concentration, crude protein concentration). Each at three levels with three replicates at the centre points was employed to fit a polynomial model:

$$
Y_{i}=\beta_{0}+\sum \beta_{i} X_{i}+\sum \beta_{i i} X_{i}^{2}+\sum \beta_{i j} X_{i} X_{j}
$$

where $Y_{i}$ is the predicted response, $X_{i} X_{j}$ are input variables which influence the response variable $Y ; \beta_{0}$ is the offset term; $\beta_{i}$ is the $i$ th linear coefficient; $\beta_{i i}$ is the ith quadratic coefficient and $\beta_{i j}$ is the ijth interaction coefficient. Design expert package (version 7.0, Stat-Ease, Inc., Minneapolis, MN, USA) was used for the experimental design and regression analysis of the data obtained.

\section{Results and Discussion}

\subsection{Screening of the Forward Extraction Conditions Using a Plackett-Burman Design}

Based on the earlier studies, a total of seven variable conditions were analyzed for their effect on forward extraction using a Plackett-Burman design. The variables chosen for the present study were $\mathrm{CTAB}$ concentration, $\mathrm{pH}$, extraction temperature, alkyl alcohol than, extraction time, $\mathrm{NaCl}$ concentration and crude protein concentration. All the variables were denoted as numerical factors and investigated at two widely spaced intervals designated as -1 (low level) and +1 (high level). The yield of forward-extraction, determined for each experimental design was shown in Table 1 . The analysis of variance (ANOVA) for the experimental designs was calculated, and the significant levels of each extraction condition were determined by $p$-value (Table 2 ). The analysis showed that CTAB concentration $\left(X_{1}\right), \mathrm{pH}\left(X_{2}\right), \mathrm{NaCl}$ concentration $\left(X_{6}\right)$, crude protein concentration $\left(X_{7}\right)$ had $p$-value below the significance level (0.05). Therefore, they were estimated to be significant (Table 2). The final equation is as follows:

$$
Y=49.6633+14.715 X_{1}-9.66167 X_{2}-10.0383 X_{6}+8.98 X_{7}
$$


Table 1. The experimental design using the Plackett-Burman method for screening of forward extraction conditions.

\begin{tabular}{ccccccccc}
\hline Run & $X_{1}^{*}$ & $X_{2}^{*}$ & $X_{3}^{*}$ & $X_{4}^{*}$ & $X_{5}^{*}$ & $X_{6}^{*}$ & $X_{7}^{*}$ & $\begin{array}{c}\text { The forward extraction } \\
\text { yield (\%) }\end{array}$ \\
\hline 1 & 40 & 8 & 20 & $4: 1$ & 20 & 0.04 & 1 & 39.36 \\
2 & 20 & 8 & 40 & $2: 1$ & 20 & 0.04 & 2 & 32.21 \\
3 & 40 & 4 & 40 & $4: 1$ & 10 & 0.04 & 2 & 72.5 \\
4 & 20 & 8 & 20 & $4: 1$ & 20 & 0.02 & 2 & 35.58 \\
5 & 20 & 4 & 40 & $2: 1$ & 20 & 0.04 & 1 & 19.36 \\
6 & 20 & 4 & 20 & $4: 1$ & 10 & 0.04 & 2 & 45.02 \\
7 & 40 & 4 & 20 & $2: 1$ & 20 & 0.02 & 2 & 82.3 \\
8 & 40 & 8 & 20 & $2: 1$ & 10 & 0.04 & 1 & 29.3 \\
9 & 40 & 8 & 40 & $2: 1$ & 10 & 0.02 & 2 & 84.25 \\
10 & 20 & 8 & 40 & $4: 1$ & 10 & 0.02 & 1 & 19.31 \\
11 & 40 & 4 & 40 & $4: 1$ & 20 & 0.02 & 1 & 78.56 \\
12 & 20 & 4 & 20 & $2: 1$ & 10 & 0.02 & 1 & 58.21 \\
\hline
\end{tabular}

" $\mathrm{X}_{1}$ : CTAB concentration $(\mathrm{mmol} / \mathrm{L}) ; \mathrm{X}_{2}: \mathrm{pH} ; \mathrm{X}_{3}$ : Extraction temperature $\left({ }^{\circ} \mathrm{C}\right) ; \mathrm{X}_{4}$ : alkyl alcohol than $(\mathrm{V}: \mathrm{V})$; $\mathrm{X}_{5}$ : Extraction time (min); $\mathrm{X}_{6}: \mathrm{NaCl}$ concentration $(\mathrm{mol} / \mathrm{L}) ; \mathrm{X}_{7}$ : Crude protein concentration $(\mathrm{mg} / \mathrm{mL})$.

Table 2. Statistical analysis of Plackett-Burman design.

\begin{tabular}{cccccc}
\hline Source & $\begin{array}{c}\text { Sum of } \\
\text { Squares }\end{array}$ & $\begin{array}{c}\text { Degree of } \\
\text { freedom }\end{array}$ & $\begin{array}{c}\text { Mean } \\
\text { Square }\end{array}$ & $\begin{array}{c}\mathrm{F} \\
\text { Value }\end{array}$ & Prob $>\mathrm{F}$ \\
\hline Model & 5895.451 & 4 & 1473.863 & 15.16151 & 0.0015 \\
$\mathrm{X}_{1}$ & 2598.375 & 1 & 2598.375 & 26.72928 & 0.0013 \\
$\mathrm{X}_{2}$ & 1120.174 & 1 & 1120.174 & 11.52314 & 0.0115 \\
$\mathrm{X}_{6}$ & 1209.218 & 1 & 1209.218 & 12.43913 & 0.0096 \\
$\mathrm{X}_{7}$ & 967.6848 & 1 & 967.6848 & 9.9545 & 0.0160 \\
Residual & 680.4755 & 7 & 97.21079 & & \\
Cor Total & 6575.926 & 11 & & & \\
\hline
\end{tabular}

$\mathrm{R}^{2}=0.896$

The multiple correlation coefficient $\left(\mathrm{R}^{2}\right)$ of this first-order model is 0.896 , which means that $89.6 \%$ of the data variation can be evaluated by the model. However, the difference between the adjusted $\mathrm{R}^{2}$ value $(83.7 \%)$ and the predicted $R^{2}$ value (69.6\%) revealed that a first-order model is not an adequate mathematical equation for demonstrating the relationship between the significant independent variables and the response. Therefore, a second-order model should be employed for further investigation.

It can be seen from Equation (2) that all the significant factors, except $\mathrm{pH}$ $\left(X_{2}\right), \mathrm{NaCl}$ concentration $\left(X_{6}\right)$ had a positive sign. Therefore, increasing their value would result in an increase in the level of forward-extraction efficiency. Further statistical analysis revealed that the difference between the means of the center point and factorial trials in this design was significant $(P<0.05)$. This indicated that the optimum levels for forward-extraction efficiency would be 
beyond the experimental ranges chosen for the Plackett-Burman design. Therefore, the steepest ascent method should be used. All the other insignificant variables were neglected and optimum combinations of these four were further analyzed by a steepest ascent design.

\subsection{Steepest Ascent}

The steepest ascent method was used to construct a line through the center of the design, due to the contribution obtained by Plackett-Burman first-order equation. Consequently, some experiments were implemented along this line with defined intervals, and the response at each point was measured. If a maximum value is found, that point could be employed as the center point for the following optimization experimental design. These results are summarized in Table 3.

\subsection{Further Optimization of the Extraction Conditions Using a Box-Behnken Design}

\subsubsection{Statistical Analysis and Model Fitting}

Experiments were carried out in duplicates to arrive at an optimum combination of the four conditions above using Box-Behnken design. Based on the results of steepest ascent experiments, Table 4 gave the design and results of experiments carried out by the Box-Behnken design. The results obtained were submitted to ANOVA on Design-expert 7.0 package and the regression model was given as

$$
\begin{aligned}
Y= & 82.244+0.1917 A+3.9 B-0.895 C-1.3483 D-1.7225 A B-1.285 A C \\
& +2.2575 A D+1.45 B C+5.3575 B D+1.015 C D \\
& -6.6749 A^{2}-4.9474 B^{2}-4.019 C^{2}-5.145 D^{2}
\end{aligned}
$$

1) Analysis of variance (ANOVA) for the extraction yield of grape seeds protein

The analysis of variance (ANOVA) was conducted to test the significance of the fit of the second-order polynomial equation for the experimental data as shown in Table 5. The Model F-value of 10.37 implies the model is significant. There is only a $0.01 \%$ chance that a "Model F-value" could occur due to noise. The $P$-values are used as a tool to check significance of each variable, which also indicate the interaction strength between each independent variable. The smaller $P$-values, the bigger the significance of the corresponding variable. $P$-values in

Table 3. Design and data from the steepest ascent experiment.

\begin{tabular}{cccccc}
\hline Run & $\begin{array}{c}\mathrm{CTAB} \text { concentration } \\
(\mathrm{mmol} / \mathrm{L})\end{array}$ & $\mathrm{pH}$ & $\begin{array}{c}\mathrm{NaCl} \\
\text { concentration } \\
(\mathrm{mol} / \mathrm{L})\end{array}$ & $\begin{array}{c}\text { crude protein } \\
\text { concentration } \\
(\mathrm{mg} / \mathrm{mL})\end{array}$ & $\begin{array}{c}\text { The forward } \\
\text { extraction } \\
\text { yield }(\%)\end{array}$ \\
\hline 1 & 30 & 6 & 0.03 & 1.5 & 55.49 \\
2 & 33 & 5.8 & 0.025 & 1.7 & 64.02 \\
3 & 36 & 5.6 & 0.02 & 1.9 & 73.24 \\
4 & 39 & 5.4 & 0.015 & 2.1 & 78.68 \\
5 & 42 & 5.2 & 0.01 & 2.3 & 71.45 \\
6 & 45 & 5 & 0.005 & 2.5 & 68.47 \\
\hline
\end{tabular}


Table 4. Box-Behnken experimental design and results for protein extraction yield.

\begin{tabular}{|c|c|c|c|c|c|c|c|c|c|c|}
\hline \multirow{2}{*}{$\begin{array}{l}\text { Trial } \\
\text { No. }\end{array}$} & \multicolumn{4}{|c|}{ Coded variables $^{\mathrm{a}}$} & \multicolumn{4}{|c|}{ Uncoded variables } & \multicolumn{2}{|c|}{$\begin{array}{c}\text { The forward extraction } \\
\text { yield (\%) }\end{array}$} \\
\hline & A & $\mathrm{B}$ & $\mathrm{C}$ & $\mathrm{D}$ & A & B & $\mathrm{C}$ & $\mathrm{D}$ & Experimental & Predicted \\
\hline 1 & -1 & -1 & 0 & 0 & 33 & 5 & 0.015 & 2.1 & 65.23 & 64.81 \\
\hline 2 & 1 & -1 & 0 & 0 & 45 & 5 & 0.015 & 2.1 & 69.2 & 68.64 \\
\hline 3 & -1 & 1 & 0 & 0 & 33 & 5.8 & 0.015 & 2.1 & 75.5 & 76.05 \\
\hline 4 & 1 & 1 & 0 & 0 & 45 & 5.8 & 0.015 & 2.1 & 72.58 & 72.99 \\
\hline 5 & 0 & 0 & -1 & -1 & 39 & 5.4 & 0.01 & 1.9 & 76.1 & 76.34 \\
\hline 6 & 0 & 0 & 1 & -1 & 39 & 5.4 & 0.02 & 1.9 & 73.24 & 72.52 \\
\hline 7 & 0 & 0 & -1 & 1 & 39 & 5.4 & 0.01 & 2.3 & 70.9 & 71.61 \\
\hline 8 & 0 & 0 & 1 & 1 & 39 & 5.4 & 0.02 & 2.3 & 72.1 & 71.85 \\
\hline 9 & -1 & 0 & 0 & -1 & 33 & 5.4 & 0.015 & 1.9 & 72.28 & 73.84 \\
\hline 10 & 1 & 0 & 0 & -1 & 45 & 5.4 & 0.015 & 1.9 & 66.23 & 69.71 \\
\hline 11 & -1 & 0 & 0 & 1 & 33 & 5.4 & 0.015 & 2.3 & 70.23 & 66.63 \\
\hline 12 & 1 & 0 & 0 & 1 & 45 & 5.4 & 0.015 & 2.3 & 73.21 & 71.53 \\
\hline 13 & 0 & -1 & -1 & 0 & 39 & 5 & 0.01 & 2.1 & 71.22 & 71.72 \\
\hline 14 & 0 & 1 & -1 & 0 & 39 & 5.8 & 0.01 & 2.1 & 79.23 & 76.62 \\
\hline 15 & 0 & -1 & 1 & 0 & 39 & 5 & 0.02 & 2.1 & 64.55 & 67.03 \\
\hline 16 & 0 & 1 & 1 & 0 & 39 & 5.8 & 0.02 & 2.1 & 78.36 & 77.73 \\
\hline 17 & -1 & 0 & -1 & 0 & 33 & 5.4 & 0.01 & 2.1 & 69.5 & 70.97 \\
\hline 18 & 1 & 0 & -1 & 0 & 45 & 5.4 & 0.01 & 2.1 & 74.23 & 73.92 \\
\hline 19 & -1 & 0 & 1 & 0 & 33 & 5.4 & 0.02 & 2.1 & 71.3 & 71.75 \\
\hline 20 & 1 & 0 & 1 & 0 & 45 & 5.4 & 0.02 & 2.1 & 70.89 & 69.56 \\
\hline 21 & 0 & -1 & 0 & -1 & 39 & 5 & 0.015 & 1.9 & 78.3 & 74.96 \\
\hline 22 & 0 & 1 & 0 & -1 & 39 & 5.8 & 0.015 & 1.9 & 73.25 & 72.04 \\
\hline 23 & 0 & -1 & 0 & 1 & 39 & 5 & 0.015 & 2.3 & 60.2 & 61.55 \\
\hline 24 & 0 & 1 & 0 & 1 & 39 & 5.8 & 0.015 & 2.3 & 76.58 & 80.06 \\
\hline 25 & 0 & 0 & 0 & 0 & 39 & 5.4 & 0.015 & 2.1 & 80.2 & 82.24 \\
\hline 26 & 0 & 0 & 0 & 0 & 39 & 5.4 & 0.015 & 2.1 & 82.56 & 82.24 \\
\hline 27 & 0 & 0 & 0 & 0 & 39 & 5.4 & 0.015 & 2.1 & 83.26 & 82.24 \\
\hline 28 & 0 & 0 & 0 & 0 & 39 & 5.4 & 0.015 & 2.1 & 82.9 & 82.24 \\
\hline 29 & 0 & 0 & 0 & 0 & 39 & 5.4 & 0.015 & 2.1 & 82.3 & 82.24 \\
\hline
\end{tabular}

${ }^{\mathrm{a}} \mathrm{A}: \mathrm{CTAB}$ concentration $(\mathrm{mmol} / \mathrm{L}), \mathrm{B}: \mathrm{pH}, \mathrm{C}: \mathrm{NaCl}$ concentration (mol/L), D: Crude protein concentration $(\mathrm{mg} / \mathrm{mL})$.

this study less than 0.01 indicate model terms are very significant. Among model terms, $B, B D, A^{2}, B^{2}, C^{2}, D^{2}$ are significant with a probability of $99 \%$. $P$-values greater than 0.05 indicate the model terms are not significant. Here the $\mathrm{R}^{2}$ value was $91.21 \%$, which could explain $91.21 \%$ variability of the response. It indicates a good agreement between experimental and predicted values and implies that the mathematical model is very reliable for protein extraction field in the present study. At the same time, a very low value 3.3 of coefficient of the variation (CV) clearly indicated a very degree of precision and a good deal of reliability of the 
Table 5. ANOVA for response surface quadratic model for protein extraction field.

\begin{tabular}{|c|c|c|c|c|c|}
\hline Factors & Sum of squares & $\mathrm{df}$ & Mean square & $F$-value & $p$-value \\
\hline Model & 856.6741 & 14 & 61.19101 & 10.37369 & $<0.0001$ \\
\hline A-A & 0.4408 & 1 & 0.440833 & 0.074734 & 0.7886 \\
\hline B-B & 182.52 & 1 & 182.52 & 30.94255 & $<0.0001$ \\
\hline $\mathrm{C}-\mathrm{C}$ & 9.6123 & 1 & 9.6123 & 1.62957 & 0.2225 \\
\hline D-D & 21.8160 & 1 & 21.81603 & 3.698464 & 0.0750 \\
\hline $\mathrm{AB}$ & 11.8680 & 1 & 11.86803 & 2.011982 & 0.1779 \\
\hline $\mathrm{AC}$ & 6.6049 & 1 & 6.6049 & 1.119726 & 0.3079 \\
\hline $\mathrm{AD}$ & 20.3852 & 1 & 20.38523 & 3.4559 & 0.0842 \\
\hline $\mathrm{BC}$ & 8.41 & 1 & 8.41 & 1.425744 & 0.2523 \\
\hline $\mathrm{BD}$ & 114.8112 & 1 & 114.8112 & 19.4639 & 0.0006 \\
\hline $\mathrm{CD}$ & 4.1209 & 1 & 4.1209 & 0.698615 & 0.4173 \\
\hline $\mathrm{A}^{2}$ & 289.0022 & 1 & 289.0022 & 48.99444 & $<0.0001$ \\
\hline $\mathrm{B}^{2}$ & 158.7693 & 1 & 158.7693 & 26.9161 & 0.0001 \\
\hline $\mathrm{C}^{2}$ & 104.8199 & 1 & 104.8199 & 17.77007 & 0.0009 \\
\hline $\mathrm{D}^{2}$ & 171.6984 & 1 & 171.6984 & 29.10796 & $<0.0001$ \\
\hline Residual & 82.58144 & 14 & 5.898674 & & \\
\hline Lack of Fit & 76.83792 & 10 & 7.683792 & 5.351277 & 0.0601 \\
\hline Pure Error & 5.74352 & 4 & 1.43588 & & \\
\hline Cor Total & 939.2555 & 28 & & & \\
\hline
\end{tabular}

experimental values.

\subsubsection{Analysis of Response Surface}

Response surface plots are shown in Figure 1, which depict the interactions between two variables by keeping the other variables at their zero levels for forward extraction yield. The effect of CTAB concentration and $\mathrm{pH}$ on the yield of extracted grape seeds protein is shown in Figure 1(a).

Figure 1(b) represents the interaction between $\mathrm{CTAB}$ and $\mathrm{NaCl}$ concentration. Lower and higher levels of both $\mathrm{CTAB}$ and $\mathrm{NaCl}$ concentration did not result in higher forward extraction yields. The shape of the response surface curves showed a moderate interaction between these tested variables.

Figure 1 (c) depicts the interaction of $\mathrm{CTAB}$ concentration and crude protein concentration where the shape of the response surface indicated no positive interaction between these two factors.

Figure 1(d) shows the effects of $\mathrm{pH}$ and concentration of $\mathrm{NaCl}$ on the forward extraction yield of grape seeds protein. This result showed that $\mathrm{pH}$ changes were more effective than $\mathrm{NaCl}$ concentration changes for yield extraction.

The graph shown in Figure 1 (e) \& Figure 1(f) indicates that $\mathrm{pH}, \mathrm{NaCl}$ concentration and crude protein concentration had a quadratic effect on protein extraction. 


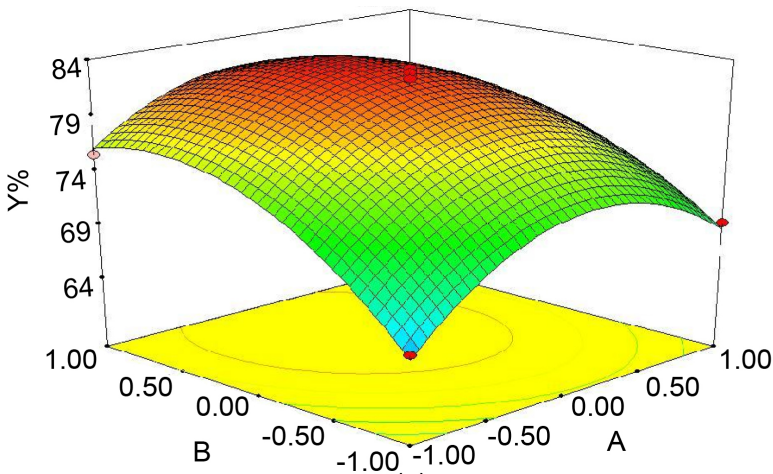

(a)

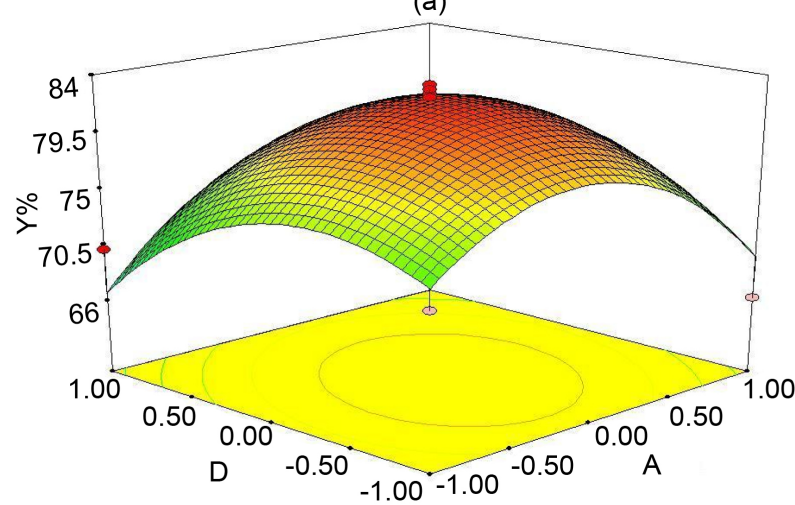

(c)

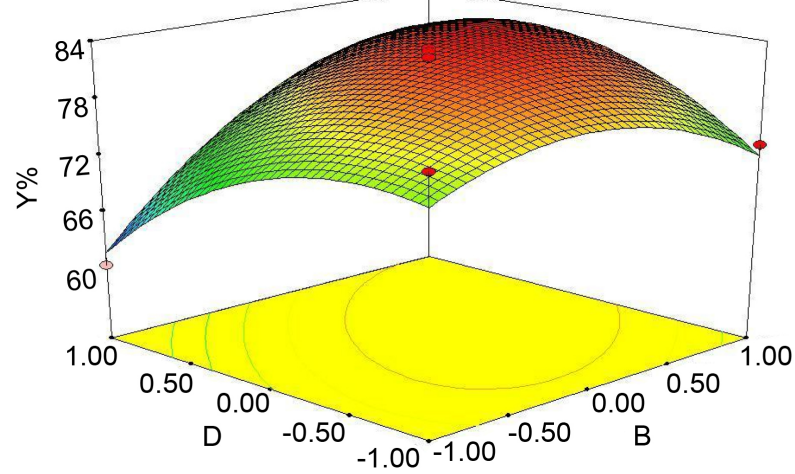

(e)

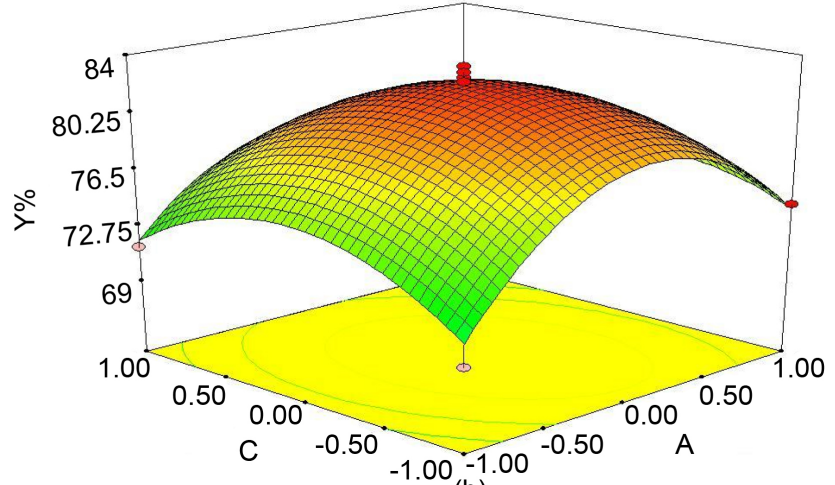

(b)

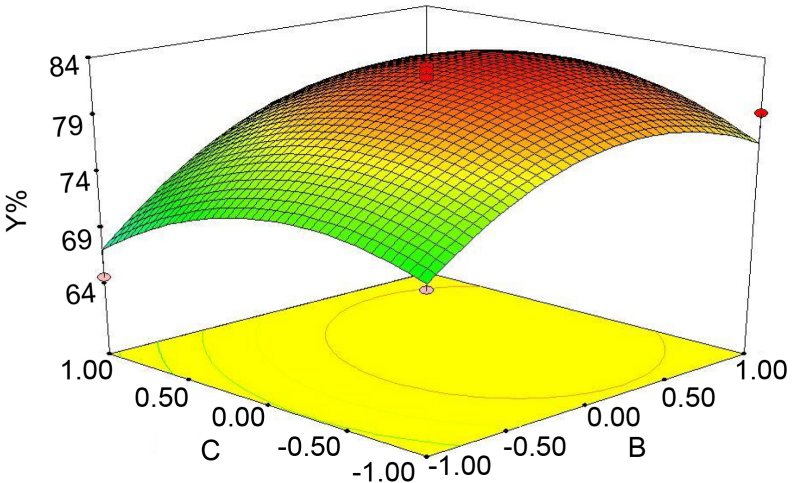

(d)

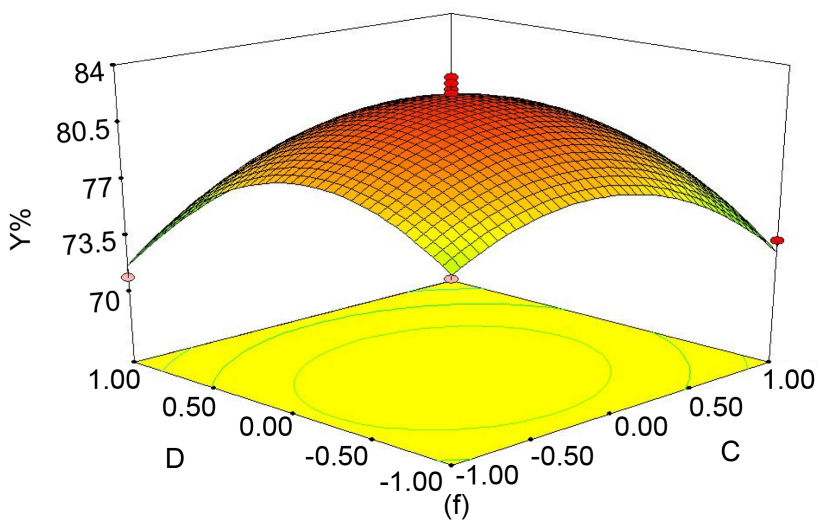

Figure 1. The response surface plot showing the effects of the forward extraction parameters on grape seeds protein yield. (a) at varying $\mathrm{CTAB}$ concentration (A) and $\mathrm{pH}(\mathrm{B}),(\mathrm{b})$ at varying $\mathrm{CTAB}$ concentration (A) and $\mathrm{NaCl}$ concentration (C), (c) at varying CTAB concentration (A) and crude protein concentration (D), (d) at varying $\mathrm{pH}(\mathrm{B})$ and $\mathrm{NaCl}$ concentration (C), (e) at varying $\mathrm{pH}(\mathrm{B})$ and crude protein concentration (D), (f) at varying $\mathrm{NaCl}$ concentration (C) and crude protein concentration (D).

\subsubsection{Optimum Conditions and Model Verification}

In order to optimize processing conditions of grape seeds protein extraction, the first partial derivatives of the regression model were equated to zero according to A, B, C and D. From the model, optimum conditions for grape seeds protein extraction were prepared as follows: $\mathrm{CTAB}$ concentration $38.84 \mathrm{mmol} / \mathrm{L}, \mathrm{NaCl}$ concentration $0.01 \mathrm{~mol} / \mathrm{L}$, crude protein concentration $2.12 \mathrm{mg} / \mathrm{mL}$. The $\mathrm{pH}$ of the aqueous phase was 5.58. Under such conditions, the yield of forward extraction process was predicted to be $83.06 \%$.

To ensure the predicted result was not biased toward the practical value, experiment rechecking was performed by using these modified optimal conditions: 
CTAB concentration $39 \mathrm{mmol} / \mathrm{L}, \mathrm{NaCl}$ concentration $0.01 \mathrm{~mol} / \mathrm{L}$, crude protein concentration $2.1 \mathrm{mg} / \mathrm{mL}$. The $\mathrm{pH}$ of the aqueous phase was 5.6. A mean value of $82.3 \%(\mathrm{~N}=3)$ was obtained from real experiment. The results of analysis confirmed that the response model was adequate for reflecting the expected optimization, and the model of Equation (3) was satisfactory and accurate.

\section{Conclusion}

The data presented in this article demonstrate the feasibility of the forward extraction of protein from grape seeds by reverse micelles. Based on the PlackettBurman design and steepest ascent, response surface methodology (RSM) was used to estimate and optimize the experimental variables: CTAB concen- tration, $\mathrm{pH}, \mathrm{NaCl}$ concentration and crude protein concentration. The optimal forward extraction conditions for grape seeds protein by reverse micelles were determined as follows: CTAB concentration $39 \mathrm{mmol} / \mathrm{L}, \mathrm{NaCl}$ concentration 0.01 $\mathrm{mol} / \mathrm{L}$, crude protein concentration $2.1 \mathrm{mg} / \mathrm{mL}$; the $\mathrm{pH}$ of the aqueous phase was 5.6. Under these conditions, the forward extraction yield of grape seeds protein was $82.3 \%$, which was closed with the predicted yield value. The data presented in this article demonstrate the feasibility of the forward extraction of protein from grape seeds by reverse micelles. Reverse micelles extraction was an efficient method compared to conventional solvent extraction. These results demonstrated the successful extraction of protein with Reverse micelles extraction, providing potential benefits for industrial extraction of protein from grape seeds.

\section{Acknowledgements}

This work has been supported by the Gansu provincial innovation foundation for technology based firms (No. 1047GCCG001), and by President Foundation of Hexi University (No. XZ2014-29).

\section{Conflict of Interest}

The authors declared that they have no conflicts of interest to this work. We declare that we do not have any commercial or associative interest that represents a conflict of interest in connection with the work submitted.

\section{References}

[1] Schieber, A., Stintzing, F.C. and Carle, R. (2001) By-Products of Plant Food Processing as a Source of Functional Compounds-Recent Developments. Trends in Food Science and Technology, 12, 401-413. https://doi.org/10.1016/S0924-2244(02)00012-2

[2] Laurent, C., Besancon, P. and Caporiccio, B. (2007) Flavonoids from a Grape Seed Extract Interact with Digestive Secretions and Intestinal Cells as Assessed in an in Vitro Digestion/Caco-2 Cell Culture Model. Food Chemistry, 100, 1704-1712. https://doi.org/10.1016/j.foodchem.2005.10.016

[3] Godevac, D., Tesevic, V., Velickovic, M., Vujisic, L., Vajs, V. and Milosavljevic, S. (2010) Polyphenolic Compounds in Seeds from Some Grape Cultivars Grown in Serbia. Journal of the Serbian Chemical Society, 75, 1641-1652. 
https://doi.org/10.2298/JSC100519131G

[4] Lafka, T.I., Sinanoglou, V. and Lazos, E.S. (2007) On the Extraction and Antioxidant Activity of Phenolic Compounds from Winery Wastes. Food Chemistry, 104, 1206-1214. https://doi.org/10.1016/j.foodchem.2007.01.068

[5] Ozcan, M.M., Unver, A., Gümüş, T. and Akin, A. (2012) Characteristics of Grape Seed and Oil from Nine Turkish Cultivars. Natural Product Research, 26, 20242029. https://doi.org/10.1080/14786419.2011.631133

[6] Zhou, T., Zhang, T., Liu, W.Y. and Zhao, G.H. (2011) Physicochemical Characteristics and Functional Properties of Grape (Vitis vinifera L.) Seeds Protein. International Journal of Food Science and Technology, 46, 635-641. https://doi.org/10.1111/j.1365-2621.2010.02532.x

[7] Vincenzi, S., Dinnella, C., Recchia, A., Monteleone, E., Gazzola, D., Pasini, G. and Curioni, A. (2013) Grape Seed Proteins: A New Fining Agent for Astringency Reduction in Red Wine. Australian Journal of Grape \& Wine Research, 19, 153-160. https://doi.org/10.1111/ajgw.12030

[8] Ozvural, E.B. and Vural, H. (2014) Which Is the Best Grape Seed Additive for Frankfurters: Extract, Oil or Flour? Journal of the Science of Food and Agriculture, 94, 792-797. https://doi.org/10.1002/jsfa.6442

[9] Sung, J. and Lee, J. (2010) Antioxidant and Antiproliferative Activities of Grape Seeds from Different Cultivars. Food Science and Biotechnology, 19, 321-326.

https://doi.org/10.1007/s10068-010-0046-6

[10] Shaker, E.S. (2006) Antioxidative Effect of Extracts from Red Grape Seed and Peel on Lipid Oxidation in Oils of Sun Flower. LWT-Food Science and Technology, 39, 883-892. https://doi.org/10.1016/j.lwt.2005.06.004

[11] Amico, V., Napoli, E.M., Renda, A., Ruberto, G., Spatafora, C. and Tringal, C. (2004) Constituents of Grape Pomace from the Sicilian Cultivar "Nerello Mascalese”. Food Chemistry, 88, 599-607. https://doi.org/10.1016/j.foodchem.2004.02.022

[12] Stankovi, M., Tesevi, V., Vajs, V., Todorovi, N., Milosavljevi, S. and Godevac, D. (2008) Antioxidant Properties of Grape Seed Extract on Human Lymphocyte Oxidative Defence. Planta Medica, 74, 730-735. https://doi.org/10.1055/s-2008-1074521

[13] Zhao, Y.M. (2009) Study on Extraction Technics of Protein from Grape Seed. Henan Science, China, 27, 1229-1232.

[14] Li, F.Y., Cui, R.J. and Li, C.H. (2005) Extraction of Protein from Grape Seed. China Oil and Fats, China, 30, 50-53.

[15] Ye, R., Ma, B.Y. and Mou, D.H. (2009) Study on Extraction Technics of Protein from Degreased Grape Seed. Sino-Overseas Grapevine \& Wine, China, 1, 17-21.

[16] Hilhorst, R., Fijneman, P., Heering, D., Wolbert, R.B.G., Dekker, M., Riet, K.V. and Bijsterbosch, B.H. (1992) Protein Extraction Using Reversed Micelles. Pure and Applied Chemistry, 64, 1765-1770. https://doi.org/10.1351/pac199264111765

[17] Leser, M.E., Luisi, P.L. and Palmieri, S. (1989) The Use of Reverse Micelles for the Simultaneous Extraction of Oil and Proteins from Vegetable Meal. Biotechnology and Bioengineering, 34, 1140-1146. https://doi.org/10.1002/bit.260340904

[18] Lye, G.J., Asenjo, J.A. and Pyle, D.L. (1994) Protein Extraction Using Reverse Micelles: Kinetics of Protein Partitioning. Chemical Engineering Science, 49, 3195 3204. https://doi.org/10.1016/0009-2509(94)00147-2

[19] Noh, K.H. and Imm, J.Y. (2005) One-Step Separation of Lysozyme by Reverse Micelles Formed by the Cationic Surfactant, Cetyldimethylammonium Bromide. Food Chemistry, 93, 95-101. https://doi.org/10.1016/j.foodchem.2004.09.012 
[20] Zhao, J.T. (2001) Study on the Use of Reverse Micelle for the Simultaneous Extraction Oil and Protein. Journal of Zhengzhou University of Technology, China, 22, 54-56.

[21] Sun, X.H., Zhu, K.X. and Zhou, H.M. (2008) Protein Extraction from Defatted Wheat Germ by Reverse Micelles: Optimization of the Forward Extraction. Journal of Cereal Science, 48, 829-835. https://doi.org/10.1016/j.jcs.2008.06.006

[22] Box, G.E.P. and Behnken, D.W. (1960) Some New Three Level Designs for the Study of Quantitative Variables. Technometrics, 2, 455-475. https://doi.org/10.1080/00401706.1960.10489912

[23] Liu, Y.Q. (2008) Experiment in Bioseparation Engineering. Higher Education Press, Beijing.

[24] Naveena, B.J., Altaf, M., Bhadriah, K. and Reddy, G. (2005) Selection of Medium Components by Plackett-Burman Design for Production of L(+) Lactic Acid by Lactobacillus amylophilus GV6 in SSF Using Wheat Bran. Bioresource Technology, 96, 485-490. https://doi.org/10.1016/j.biortech.2004.05.020

[25] Hasan-Beikdashti, M., Forootanfar, H., Safiarian, M.S., Ameri, A., Ghahremani, M.H., Khoshayand, M.R. and Faramarzi, M.A. (2012) Optimization of Culture Conditions for Production of Lipase by a Newly Isolated Bacterium Stenotrophomonas maltophilia. Journal of the Taiwan Institute of Chemical Engineers, 43, 670677. https://doi.org/10.1016/j.jtice.2012.03.005

Submit or recommend next manuscript to OALib Journal and we will provide best service for you:

- Publication frequency: Monthly

- 9 subject areas of science, technology and medicine

- Fair and rigorous peer-review system

- Fast publication process

- Article promotion in various social networking sites (LinkedIn, Facebook, Twitter, etc.)

- Maximum dissemination of your research work

Submit Your Paper Online: Click Here to Submit

Or Contact service@oalib.com 